\title{
Moral Values Of Main Character In Bumblebee Movie Directed By Travis Knight
}

\author{
Yanti Rosalinah $^{1}$, Syifa Aulia ${ }^{2}$, Ibnu Subroto ${ }^{3}$ \\ 1, 2, 3 Universitas Bina Sarana Informatika \\ e-mail: ${ }^{1}$ yanti.yaa@ bsi.ac.id, ${ }^{2}$ paunglia172@gmail.com, ${ }^{3}$ ibnu.isb@bsi.ac.id

\begin{tabular}{ccc}
\hline Diterima & Direvisi & Disetujui \\
$02-09-2021$ & $23-09-2021$ & $29-09-2021$ \\
\hline
\end{tabular}

Abstract - Nowadays, watching a movie has become a daily activity for some people, even become a hobby. Sometimes humans just watch and forget some important things we can take from the movie. One of them is a moral value that we can set as an example to deal with various problems of life. That is the purpose of this paper. The writer wants to convey the moral values that can be taken from the film to the readers or viewers of the movie. In analyzing this paper, The writer uses descriptive qualitative method and the techniques by descriptive observation (collecting). So here, The Writer will examine the bumblebee film with data in the form of words and images from the film. Then the procedure for collecting data using observation techniques (field notes). Collecting technique the data needed and the theory is through internet research. The result of this research is first, types of moral values in Bumblebee that appear in the movie and the second is which types of moral value most appear in the movie. There are eight types of moral values in this movie. They are patriotism, work hard, friendly or communicative, creative, care to social, curious, independent, and appreciate achievement.

\section{Keywords: Moral values, Main characters, Movie}

Abstrak - Menonton film saat ini sudah menjadi keseharian sebagian orang, bahkan menjadi hobi. Terkadang manusia hanya menonton dan melupakan beberapa hal penting yang bisa kita ambil dari film tersebut. Salah satunya adalah nilai moral yang dapat kita jadikan contoh untuk menghadapi berbagai permasalahan kehidupan. Itulah tujuan dibuatnya makalah ini. Penulis ingin menyampaikan nilai-nilai moral yang dapat diambil dari film tersebut kepada pembaca atau penonton film tersebut. Dalam menganalisis, Penulis menggunakan metode deskriptif kualitatif dan teknik yang digunakan adalah observasi deskriptif (mengumpulkan). Disini penulis akan mengkaji film Bumblebee dengan data berupa kata-kata dan gambar dari film tersebut. Kemudian prosedur pengumpulan data menggunakan teknik observasi (catatan lapangan). Teknik pengumpulan data yang dibutuhkan dan teori melalui penelitian internet. Hasil dari penelitian ini adalah pertama jenis nilai moral dalam film Bumblebee dan kedua jenis nilai moral yang paling banyak muncul dalam film. Ada delapan jenis nilai moral yang terdapat di dalam film ini. Yaitu patriotisme, bekerja keras, ramah atau komunikatif, kreatif, peduli pada sosial, rasa ingin tahu, mandiri, dan menghargai prestasi.

Kata Kunci: Nilai Moral, Karakter Utama, Film

\section{INTRODUCTION}

Literature is a Latin word "littera" which means letter. A Literary production body, both oral and written or visual that contains describing the thoughts, emotions, and experiences of the human condition is literature. The form of human expression is literature. There are five main genres of literature, they are poetry, prose, drama, non-fiction, and media. And in this paper, the writer talks about action and science fiction movies. It can discuss many things, such as plot, character, and setting. But the writer takes about the moral value because sometimes the readers cannot find the moral value from the movie.

According to (Lindy, 2018) Something close to human life has a relationship with literature. Literature is even the life itself, which deals with all aspects of human beings' activities, any kinds of phenomena in the universe, series of horizons and knowledge owned by the human beings, and any symptoms being beyond the human beings' lives. These all happen due to the sharpness of thoughts, the bunch of knowledge, and the waves of imagination. (Nuriadi, 2016). It means that the form of human is literature. Literary work closely related to psychology, because they have the same object, that is human life. Film is one of the literary works that represent the reality of human life in society.

As said by (Fani, 2018) in her journal, "Literature is a term used to describe written and sometimes spoken material. Derived from the Latin Litteratura meaning "writing formed with letters," literature most commonly refers to works of the creative imagination, including poetry, drama, fiction, and nonfiction". It means literature can serve as an introduction to experience in a new world, because literature is more than history. 
While (Am, Y. T., Kuncara, S. D., \& Setyowati, 2017) said that "The literary influence in the movie is one of the developments in the movies. The development of literature in the movies itself can be seen by seeing the fact that many movies are made based on the story in a literary work". That means the influence of literature in film is one of the film developments that can be seen based on the fact that many films are made based on a literary work.

In other side, According to (Effendi, 2015) "Literature is a creative, an art; the other, if not precisely a science, is a species of knowledge or of learning." (Wellek, Rene; Warren, 1948). It means literature is a creative art or an art of creativity, and literature is also a part of learning or of knowledge.

From all the statements above, it can be concluded that literature is the creative commitment of a work of art related to human life. And one type of literary work is a movie. In this paper, the writer analyzes the moral values of the movie or film. Sometimes humans just watch and forget some important things we can take from the movie. One of them is a moral value that we can set as an example to deal with various problems of life. For example, such as caring for each other living creatures and the environment, being responsible for what is ordered, being kind to anyone, not being prejudiced, and so forth. It all includes the moral values that can be imitated by the audience to be applied in everyday life that will be valuable in the family and environment.

In doing this research, the writer has found the previous research finding that gives inspiration to the writer about the moral value found in Bumblebee movie. These research are as follows. The first is the research by Danesa Ismiyana Noumiyanti titled, "Character Values in Zootopia Movie Directed by Byroon Howard and Rich Moore". The second previous research is by Mohamad Zaenuri Arif and Asih Kuswandari, titled "An Analysis of Moral Value In the Movie Entitled "Saving Mr. Banks" Based on Its Intrinsic Value".

The difference from this paper is Bumblebee movie is one of the movie that has many moral lessons. The movie tells us about love, caring for each other, responsibility, and patriotism. Audiences can get many lessons from this movie. One of the powerful lessons from this movie is care. Care to social, care for each other, helping each other, being kind to everyone, and not forgetting the responsibility assigned to him.

The reason the writer analyzes moral values is because moral values are very important and influential in human life and the writer wants to convey the moral values that can be taken from the film to the readers and viewers of Bumblebee movie. Therefore, here the writer will analyze the moral values in this movie from the main characters Charlie Watson and Bumblebee.

\section{RESEARCH METHODOLOGY}

This paper uses a descriptive qualitative method according to $(M, 2010)$ wrote that the qualitative descriptive design facilitates a "comprehensive summary of an event in the everyday terms of those events". So the qualitative descriptive study illustrates a summary of an event accurately or comprehensively. The techniques of the study were related to (Sugiyono, 2011)by descriptive observation (collecting). So here, the writer will examine the bumblebee film with data in the form of words and images from the film. The procedure for collecting data is using observation techniques (field notes) and internet research.

The procedure of analysis begins with the writer chooses one of the best films from many good films and watches it many times to make sure the writer knows the story and the moral values in the film. By using theory from (Mulyasa, 2009) about moral values, each data is then explained fully. The final procedure is the writer finds the material and references relate to Bumblebee movie and then the writer finds out what moral values are contained in the Bumblebee movie and the moral values most often shown in Bumblebee movie. After analyzing it, the writer concludes about moral values that could be taken away as a lesson or positive things for human life for the viewers, the readers, and for human life.

\section{FINDING AND RESULT}

According to Mulyasa, there are eighteen types of moral values. But, in this movie, the writer found 8 types of moral value. They are patriotism, work hard, friendly or communicative, creative, care to social, curious, independent, and appreciate achievement. In this part, the writer will explain how and when did the moral values appear in the movie.

\section{Patriotism}

Patriotism is ways of thinking, behaving, and acting that show loyalty, care, and high respect for the language, physical environment, social culture, economy, and politics of the nation. Patriotism appears when one's behavior shows loyalty, care, and high respect for the nation. For example, never give up and be willing to sacrifice for the benefit of the nation and state. 


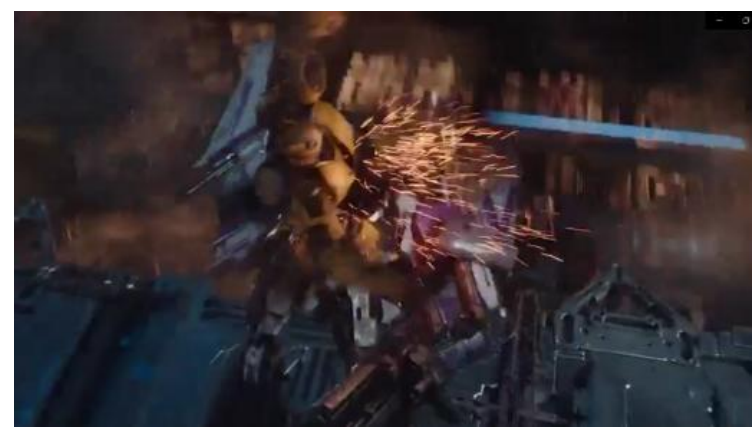

Figure 1. When B-127 Attacked the enemies (0:01:27)

B-127 : "Optimus, this is our home! We have to fight for it."

Optimus : "We will fight on, but we must find refuge first"

Optimus : 'I've found a planet that's well hidden. Earth. You will travel there and establish a base for us. Once we've gathered the others, we'll join you. You must protect the planet. If the Deceptions find it, then our people are truly finished. Now go!"

There was a big war between the Deceptions and Autobots. deceptions want to take Cyberton (where the Autobots live) from the Autobots. At that time the B-127 arrived late to help Optimus because of traffic. However, after arriving at Cyberton, B-127 immediately attacked all enemies and approached Optimus. Then Optimus gave the task to B-127 to go to Earth to find a safe place that can be inhabited by the Autobots.

The writer can find patriotism in B-127's character because, in the scene, he fought against enemies who had destroyed his residence and nation, and based on the dialog "Optimus, this is our home! We have to fight for it" he said that he would continue to fight against enemies to take back their home. B-127 is a brave robot does not give up easily in fighting enemies, and is willing to sacrifice for the nation and country. Those are the qualities that show patriotism.

\section{Work hard}

Work hard is behavior that shows earnest effort in overcoming various learning barriers and tasks, and completing tasks properly. For example, study hard, have the will to try, do not give up when you get a failure and do not stop trying, discipline on time or not getting used to stalling, able to motivate, be brave towards all kinds of risks that exist, and have a positive belief such as being sure to succeed.

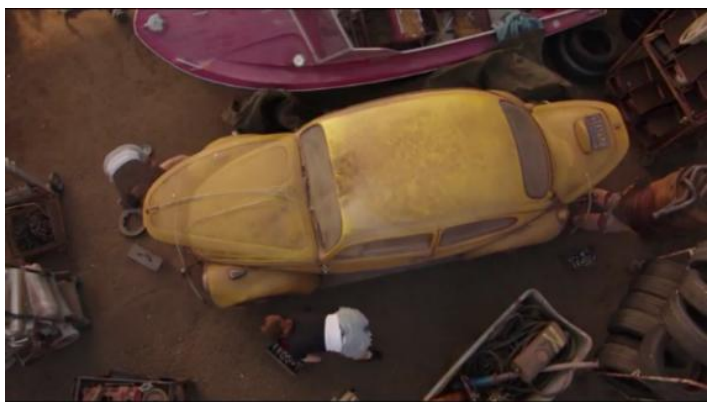

Figure 2. Charlie fixing the car $(0: 25: 38)$

Uncle Hank : “That's no deal. That's just you taking my car"

Charlie

: "If I can start it, I keep it andand I work here every day for a year. I'll scrub the grease off the floors, okay?"

One day before Charlie's birthday, Charlie went to the Uncle Hank's garage and found a Yellow VW Beetle there. Tomorrow, Charlie decided to fix that car and ask Uncle Hank to give her the car if she can fix it, she even offered to help Uncle Hank clean the garage every day and work every day for a year for that car. Then Charlie was worked hard to fix that car until finally, she did it. She fixed the car, and brought that car to her home.

The writer can find Work Hard in Charlie's Character. Work Hard appear from Charlie's character because she wants the car. When she wants something and believes that she can do it, she will work hard to get it. From the dialog "If I can start it, I keep it and-and I work here every day for a year. I'll scrub the grease off the floors, okay?" the writer can say that Charlie is a hard worker because she has the will to try, she doesn't give up when fixed the car, and she brave towards all kinds of risks that exist like as she said that she will works every day in that garage just for the car. She is also has a positive belief that she will be a success in fixing that broken car.

\section{Friendly or communicative}

Friendly or communicative is meant that actions show pleasure in talking, hanging out, and working with others. For example, when you meet a new friend at school or wherever, you introduce yourself to him, talk to him to get to know each other. Such as loves to interact with people from around the world, likes to make friends with anyone without choosing, or likes to work with others. It's also friendly or communicative.

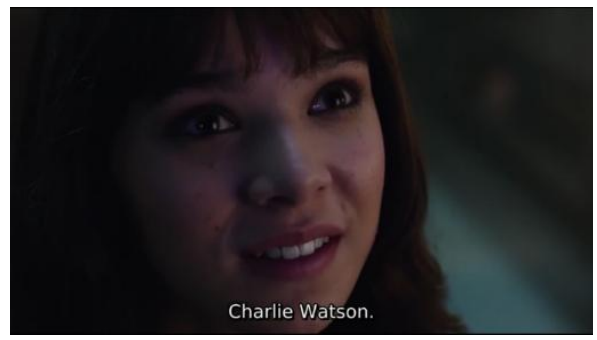


Figure 3. Charlie introduce herself (0:31:44)

Charlie

: "Oh I am.. Charlie. Charlie Watson. I'm eighteen. Today, actually, it's my birthday today. What's your name?"

Bumblebee : (Shook his head)

Charlie : "You don't know or you don't have a name?"

Charlie : "You sound like a little bumblebee. And I'm gonna call you that from now on. Bumblebee. It matches to your outfit too"

After she brought her car to her home and put it in the garage, suddenly at the bottom of the car there was something hit the floor. A surprising thing happened, the car turned into a robot. Afraid of the robot being evil, Charlie, who was still surprised, tried to open the garage door and wanted to leave. But when she saw that the robot was very innocent and afraid of her, Charlie closed the door again and approached the robot. Charlie asked if he could understand the language and asked who he was and where he came from. Then after being appointed by Bumblebee, Charlie introduced herself starting from her name, and also her age.

The writer saw it as friendly or communicative moral value because based on the dialog "Oh I am. Charlie. Charlie Watson. I'm eighteen. Today, actually, it's my birthday today. What's your name?", Charlie introduces herself, her age and even she said today was her birthday. Charlie tells about herself to Bumblebee. With a very friendly Charlie opened the conversation with the robot, she even gave the robot a name, Bumblebee.

\section{Creative}

Creative is when think and do something to produce a new way or result from something you already have. There are so many examples of creative behavior, for example, changing used goods that are not used into something that can be used or change goods that are damaged and cannot be used into something new and can be used and also change natural goods that are not used into something which can be used like making bags from leaf material.

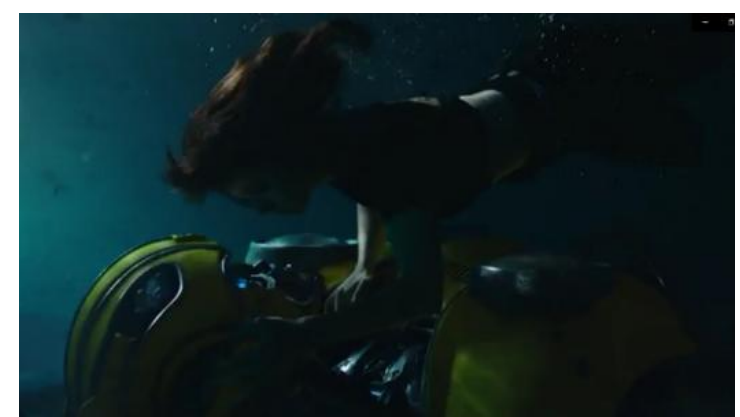

Figure 4. Charlie fix Bumblebee's broken radio
Bumblebee

: (Watching Charlie's video)

Charlie : "No. why did you play this?!"

Bumblebee : (Feeling afraid)

Charlie : :I'm sorry, just---, I finished. Let's see we got something" (take a chair and put in the radio)

Charlie : "Okay. Okay..Alright. Oh my god! Yes! It worked!” (Happy)

After returning from the forest and returning home, according to his promise Charlie will justify the damaged Bumblebee radio so that it can function properly again. While Charlie was fixing the broken radio, Bumblebee watched television. Then, Bumblebee saw a cassette with the words "Charlie Dive Meet". Bumblebee watched it but when Charlie found out, Charlie scolded Bumblebee for watching the tape. Bumblebee was afraid of that, then Charlie apologized and gave the radio she had fixed. How happy Charlie was when she got the radio working again.

It can be conclude that Creative appears because Charlie fixes the broken car into something that can be used again. Based on dialogue "Okay. Okay..Alright. Oh my god! Yes! It worked!” explain that Charlie did it, she succeeded in fixing the radio. As the writer said before, change goods that are damaged and cannot be used into something new and can be used is creative behavior. This shows that Charlie is a creative teenager.

\section{Care to social}

Care to social is about the attitudes and actions that always want to assist other people and communities in need. For example, helping each other, helping people who are in distress, empathizing with others, sharing with others, participating in entertaining people who are in disaster or comforting someone sad, and many more. If you a kind-hearted person you'll love helping people.

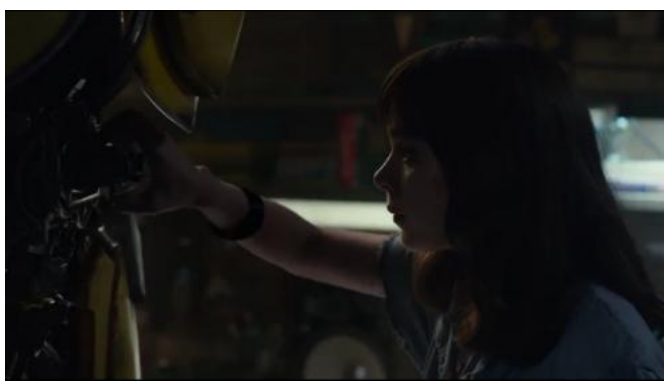

Figure 5. Charlie rescued Bumblebee

$\begin{array}{ll}\text { Shatter } & \text { : "No." (try to kill Charlie) } \\ \text { Bumblebee } & \text { : (attack Shatter) } \\ \text { Shatter } & \text { : "After I kill you. I kill her!" } \\ \text { Bumblebee } & \text { : (blow up the water dike) } \\ \text { Shatter } & \text { : "Ha-haa! You missed!" (looking the } \\ & \text { dike) "You'll kill us both!" }\end{array}$

Shatter : "No." (try to kill Charlie)

Bumblebee : (attack Shatter)

: "After I kill you. I kill her!"

: (blow up the water dike) dike) "You'll kill us both!" 
Charlie

Charlie

: "Bumblebee!"

: (turn into water and safe Bumblebee)

Charlie could not see Bumblebee struggling alone. Charlie also helped Bumblebee by climbing the tower to cancel the Deceptions plan that sent transmissions to his planet to send soldiers to Earth and destroy the Earth. when Charlie reached the top and wanted to deactivate the transmission, Shatter who saw Charlie trying to thwart her plan immediately wanted to shoot Charlie. However, the attempt failed because Bumblebee attacked Shatter so she could not hurt Charlie. Furious with that, Shatter beat Bumblebee to the point of weakness. Shatter threatened to kill Charlie after killing Bumblebee. Unable to fight Shatter and afraid of Charlie being hurt, Bumblebee decides to shoot the water embankment in front of him which can make them both die. They both sank. Charlie, who saw Bumblebee drowning, finally gathered the courage to dive and helped Bumblebee even though she hadn't been diving for a long time after her father's death.

It can be conclude that care for society appears because they care for each other. Bumblebee does not want something bad happened to Charlie, also with Charlie. In dialog explain that Bumblebee shoots the water embankment to help Charlie and Charlie diving to help Bumblebee. As the writer explains before that care to society can be helping someone or people. That is the behavior shown by Charlie and Bumblebee, helping each other. Helping is Caring.

\section{Curious}

Curious is when attitudes and actions always try to find out deeper and broader than something that is learned, seen, and heard. Everyone must have a curiosity even though the slightest. There are many kinds of curiosity such as curiosity about the lesson, or curious to learn more in something that has been learned, curious about something that has never been found, and one of them is curious about someone, and many more.

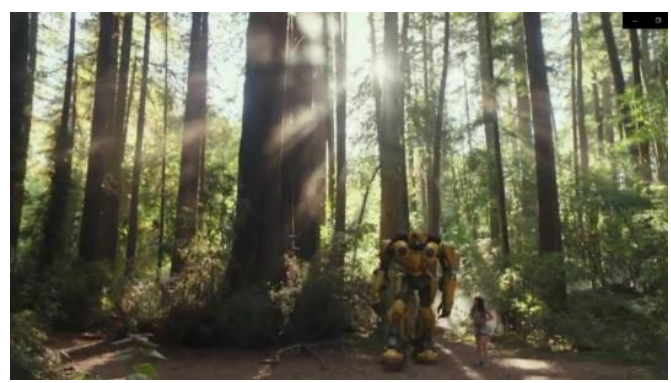

Figure 6. Charlie asked many questions to Bee

Charlie : "It sucked being couped up in a VW all day, huh?"

Charlie : "Is there-- anyone can help you?"

Charlie : "Do you have a family? You know, like a mom, dad, or siblings. You all love each other or drive each other crazy and you can't wait to get away and start your own life."

After teaching Bumblebee some things that should and should not be done, they walk around the forest. At that moment Charlie asked Bumblebee a lot of questions. But because Bumblebee could not speak, Bumblebee did not answer. But Charlie didn't stop asking questions about deep things. Then Bumblebee shows Charlie his broken part and asks him to fix it.

Based on the dialog above, the writer can saw that Curious appeared when Charlie asked many things to Bumblebee because she wants to know about him. As the writer explained before there are many kinds of curiosity and one of them is curious about someone. It also shows curiosity. Charlie was so curious about Bumblebee, Bumblebee's life, Bumblebee's family, Bumblebee's feeling for being a yellow VW Beetle, she wants to know all about him. She wants to know Bumblebee more deeply.

\section{Independent}

Independent is attitudes and behaviors that do not easy depend on others in completing tasks. There are many examples of independent attitudes that can be used as lessons. Like not always dependent on others for example not depend on parents to pay for your life. Utilizing time as well as possible also includes an independent attitude, if you cannot manage your time you will never live independently because it means you cannot manage yourself.

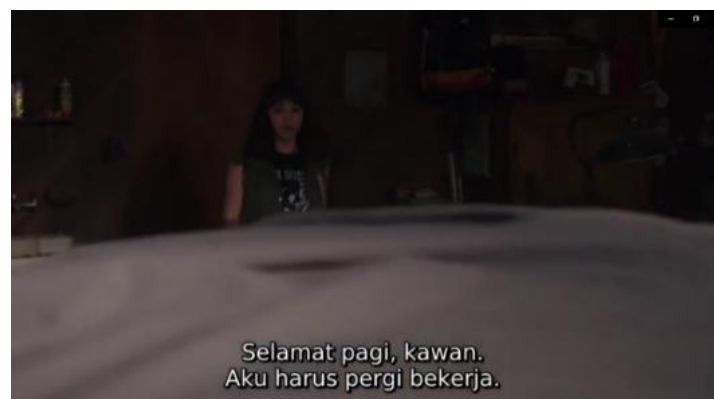

Figure 7. Charlie wants to go to work (1:06:02)

\begin{tabular}{|c|c|}
\hline Charlie & $\begin{array}{l}\text { : "Come on now, buddy. I gotta go to } \\
\text { work, okay?" }\end{array}$ \\
\hline Charlie & $\begin{array}{l}\text { :"Bee, listen to me. You need to stay in } \\
\text { the garage, okay?" }\end{array}$ \\
\hline Charlie & $\begin{array}{l}\text { "After what happened last night, I'm } \\
\text { pretty sure the cops will be looking } \\
\text { for you. And you don't exactly want } \\
\text { it. I'll be back, alright?" }\end{array}$ \\
\hline Charlie & $\begin{array}{l}\text { : "Here. You're taking my pop-tart" } \\
\text { (give her bread to Bumblebee) }\end{array}$ \\
\hline
\end{tabular}

In the morning, Charlie, who was ready to work, immediately ate pop-tart as his breakfast. Before leaving for work she approached Bumblebee and said good-bye to work. Bumblebee opened the door 
thinking that Charlie would go with him. But apparently not, Charlie told Bumblebee to stay in the garage because surely the cops were looking for him for what had happened last night by Bumblebee. Charlie covered Bumblebee's body with a large cloth. Then she gave Bumblebee his pop-tart.

From the dialogue above we can know that the emergence of an independent attitude because Charlie also works to make the income that she can use for his needs. Previously The Writer has explained that independence does not always depend on others. Charlie does not depend on his parents' income, she works for herself, she can also arrange the time when she has to get up to work. It is proof that she is an independent girl.

\section{Appreciate achievement}

Appreciate Achievements are attitudes and actions that encourage him to produce something useful for society, and recognize, and respect the success of others. For example, respect, appreciate things that have been made by someone, appreciate the work of others, appreciate the efforts of others, be fair, do not insult or ridicule, give support, respect the opinions of others. If the school environment respects the teacher who is teaching in front of the class.

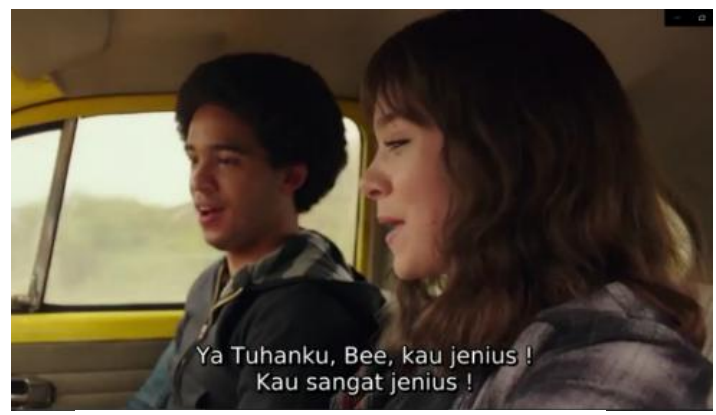

Figure 8. Charlie said Bumblebee was Genius (0:57:11)

Memo

from?"

Charlie

Memo

cops?"

Charlie

: "So you've no idea where he came

: "No idea"

: "Have you tought about calling the

: "What are they gonna do, Memo? They just gonna send him away to a lab and do weird science experiments on him"

Bumblebee : "Weird science ", "Plastic tubes and pots and pans" (Switching over the radio channel)

Charlie : "You're getting pretty good with that radio dial, Bee"

Memo : "DJ Bumble in the house! Woo-

hoo"

Charlie : "Is that why you're always messing with the dial? You're trying to teach yourself how to talk, aren't you?"
Bumblebee

: (Still switching over the radio channel)

Memo

Charlie

\author{
: "No way!" \\ "Oh my god, Bee! You're genius! \\ You're an actual genius!"
}

Charlie, Bumblebee, and memo go around to play together. On the trip, Memo asked about where Bumblebee came from, but Charlie also didn't know. Then Memo proposes Charlie to contact the police and Charlie refuses because they will do strange science experiments on Bumblebee. And at that moment Bumblebee played the song instead of talking by playing the radio channel. Charlie praised Bumblebee and finally understood that Bee had been trying to talk to them using his radio.

The writer saw it as appreciate achievement moral value because based on the dialog "Oh my god, Bee! You're genius! You're an actual genius!" that shows appreciation Bumblebee. Charlie appreciates Bumblebee who was so creative because he speaks using radio. Exactly speaks to Charlie and Memo by switching over the radio channel. As the writer said before, appreciate the efforts of others. Charlie appreciated Bumblebee by saying that he was a genius and he was an actual genius.

\section{A. Types of Moral Values Which Most Appear in Bumblebee Movie}

In this part, the writer will discuss about moral values that most appear in Bumblebee movie according to Mulyasa. They are work hard, creative, care to social, and curiosity.

\section{Work Hard}

In this movie, work hard can be found when Charlie didn't stop fixing the broken car.

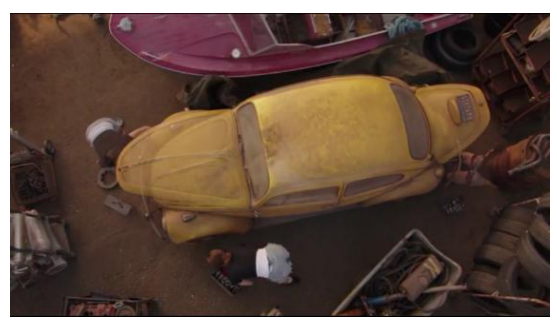

Figure 9. When Charlie working hard to fix the broken car $(0: 17: 48)$

Work hard in this movie could be describe in scene and dialog as follow:
Charlie
: "Hi, Uncle Hank"
Uncle Hank : "Are you still working that damn car?"
Charlie : "Are you still working on that damn personality?"
Charlie : "What do you have for me?" 
Uncle Hank : "Whatever you want. The Russians on the blow us all the hell, anyway."

Charlie : "That's the spirit"

Charlie comes to Uncle Hank to take machine tools for fixing her car. She also takes a boat machine which is not used. Uncle Hank said that Charlie always works for that broken car. She often comes there just for the new tools that she can use to fix the car. She had one of her father's car, but it broke down. So, she has to fix it until it's fully operational again.

Work hard is behavior that shows earnest effort in overcoming various learning barriers and tasks, and completing tasks properly. According to Gunawan, hard work is a behavior that shows earnest effort in overcoming various obstacles in order to complete a task (study/work) as well as possible.

In this dialog, the writer can saw work hard from Charlie's Character. Uncle Hank also knows that Charlie never gives up on fixing her father's car until it can work again. Charlie really wants a car, she had one of her father's car, but it broke down. So, she has to work hard to make it true. Work hard in this movie could be describe in scene and dialog as follow:

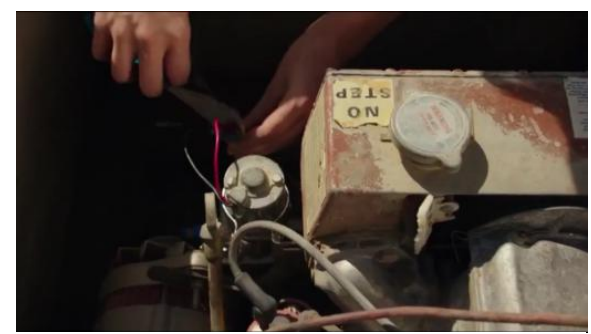

Figure 10. When Charlie fix a yellow VW Beetle (0:25:38)

Charlie : "I want the Beetle"

Uncle Hank : "What?"

Charlie : "The yellow beetle. I want it. I'll make you a deal. If I get that thing started, its fine"

Uncle Hank : "That's no deal. That's just you taking my car"

Charlie : "If I can start it, I keep it andand I work here every day for a year. I'll scrub the grease off the floors, okay?"

Charlie : "I'll pick up and organize every scrap of paper in this place. I'll even detail your horrible, disgusting toilets. Please, it's my birthday"

Uncle Hank : "Sorry, no deal. Cause we ain't hiring"

It was Charlie's Birthday. Charlie comes again to Uncle Hank and decided to take the Beetle. She asked to Uncle hank to give her the yellow beetle and she will be working in a garage instead. But Uncle
Hank gives that broken car for free as her birthday gift. Charlie started to fix that car and pray to god, hope the car will work again. Eventually, the car was right and she took it home.

In this dialog, the writer can saw work hard from Charlie's Character. Charlie really wants that VW Beetle car. Based on the dialogue "If I can start it, I keep it and-and I work here every day for a year. I'll scrub the grease off the floors, okay?" She promised that she will work every day in the garage and clean all if she can take Bumblebee when she can fix it. She needs to work hard to get that car and for fixing the car

\section{Creative}

It appeared when Charlie and Bumblebee walk around and Charlie knew about Bumblebee's broken radio because attacked by Deceptions, Charlie creatively fixes the radio. Creative also appeared in Bumblebee's character when he tried to speak with Charlie by switching over that radio channel.

Think and do something to produce a new way or result from something you already have. According to Sadiq (2010), creative understanding is an idea of concepts and plans for progress, these ideas are needed in the thinking and also the work of a person in solving social problems that are developing. Creative thinking will produce ideas that are unique and not thought of before. The idea is a thought that creates a solution to the problems that exist in society.

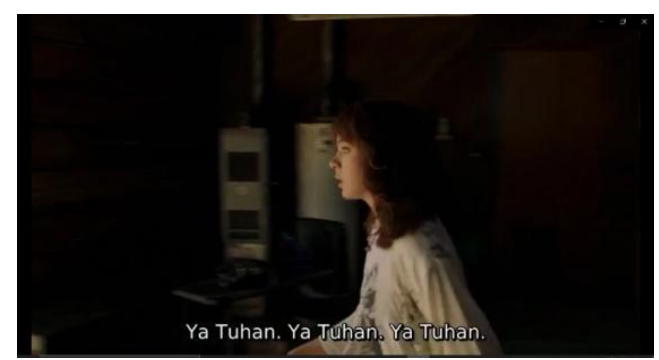

Figure 11. When Bee switching over the radio channel (0:56:56)

Creative in this movie could be described in the scene and dialog as follow:

Charlie : "You're getting pretty good with that radio dial, Bee"

Memo : "DJ Bumble in the house! Woo-hoo"

Charlie : "Is that why you're always messing with the dial? You're trying to teach yourself how to talk, aren't you?"

Bumblebee : (Still switching over the radio channel)

Memo : "No way!"

Charlie : “Oh my god, Bee! You're genius! You're an actual genius!

Charlie, Bumblebee, and memo go around to play together. On the trip Memo asked about where 
Bumblebee came from, but Charlie also didn't know. Then Memo proposes Charlie to contact the police and Charlie refuses because they will do strange science experiments on Bumblebee. And at that moment Bumblebee played the song instead of talking by playing the radio channel.

From the dialog "Is that why you're always messing with the dial? You're trying to teach yourself how to talk, aren't you?", the writer can find the creativity of Bumblebee. Charlie said that Bumblebee try to speak with Charlie and Memo using the radio by switching over the channel. So, now they can communicate with each other.

\section{Care to Social}

In this movie, the audience will notice how care Charlie and Bumblebee. When Bumblebee lost, Charlie was panicked and afraid if someone stole it. After that Charlie teach Bumblebee how if there's human except Charlie to avoid unwanted accidents.

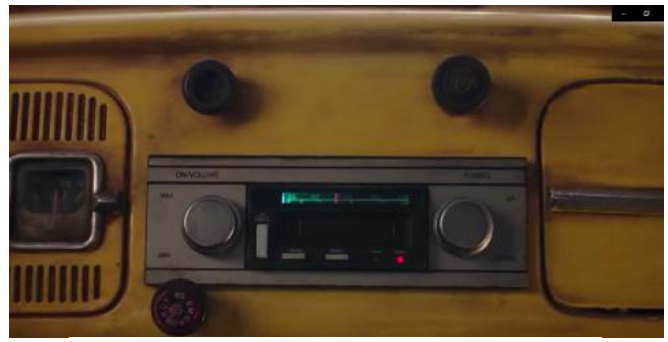

Figure 12. When Bumblebee was gone $(0: 35: 29)$

Care to social in this movie could be described in scene and dialog as follow:

$\begin{array}{ll}\text { Charlie } & \text { "Good morning, Bum----Bee? } \\ & \begin{array}{l}\text { Bee? Where are you?" } \\ \text { (panicked) }\end{array} \\ \text { Charlie } & : \text { "God! Oh, God! Oh, God! Bee! } \\ & \text { Where did you go?" (looking } \\ & \begin{array}{l}\text { around) } \\ \text { Charlie }\end{array} \\ & \text { "Otis! Have you seen my car? } \\ \text { (asking to her young brother) } & \text { "Unfortunately, yes." } \\ \text { Otis } & : \text { "No, Otis, have you seen my car } \\ \text { Charlie } & \text { today? It was-It was in the } \\ & \text { garage. Someone's stole it!" }\end{array}$

According to Retno Listyarti, Social care is the attitude and actions that always want to assist other people and people in need. Care to social is about the attitudes and actions that always want to assist other people and communities in need. For example: helping each other and many more.

From the dialog "God! Oh, God! Oh, God! Bee! Where did you go?" shows that Charlie so cares about her car, Bumblebee. When she doesn't see him, she will be panicked and looking for him everywhere and asking everyone if anyone sees her car. And when she knew that her car was taken by her mother to go to the vet, she was more panicked because she was afraid if Bumblebee does something strange like showing himself that he was a robot or anything else. It was cared to social. Care to social in this movie could be described in scene and dialog as follow:

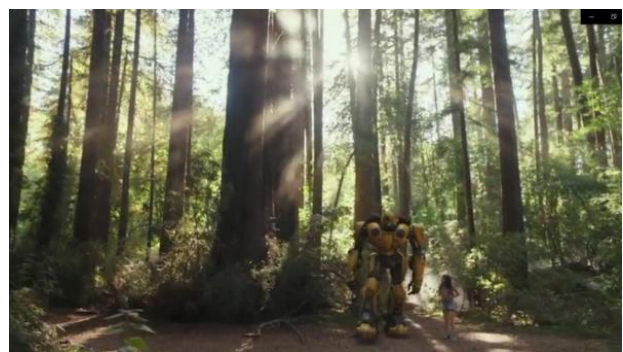

Figure 13. When Charlie asked help to Memo for help Bumblebee (1:18:53)

Television : "Residents of Brighton Falls have been witnessed to an unusual sight this Evening. Armed forces pouring in to town as a part of what we were told, is a routine military exercise, setting up camp at our own McKinon air base-----"

Charlie : "If Bumblebee still alive, that's where they keeping him. We have to go. We have to try and safe him"

Otis

Charlie

: "Count me in. I'll take point"

Otis

Charlie

Otis

Charlie

: "No. You won't"

: "Come On.."

: "No. Otis."

: "But I can help. Mr. Larry---"

: "Look, I need someone here. I need someone reliable to make sure that Mom and Ron don't know that I'm gone"

Otis : "I am someone reliable"

Charlie : "Hell, Yeah. You're"

Otis : "Good luck!"

Charlie went to Memo's house to ask for help to save Bumblebee. Charlie also asked Otis for help, so her parents wouldn't know she was gone. After that, they went to the place where Bumblebee was locked down and try to save him. When they arrived, they saw Deceptions tortured Bumblebee and killed Mr. Powell. And after Deceptions went out, Charlie and Memo enter and safe Bumblebee.

The writer can find Care to Social in Charlie's character based on the dialog "If Bumblebee still alive, that's where they keeping him. We have to go. We have to try and save him" Charlie said to Memo that they have to go and try to safe Bumblebee. And Memo agrees with that. they went to McKinon to save Bumblebee. Helping someone in a dangerous time is one of care to social.

From all the actions in the dialog, it shows care to social. Bumblebee's action to fight Shatter is because he cares to Charlie. And Charlie's action to dive into the water is because she cares to Bumblebee 
and wants to safe him. They help each other, they also care each other.

\section{Curiosity}

In this movie, curiosity appeared when Charlie gives so many questions to Bumblebee. It means Charlie was so curious about who is Bumblebee and where is he lives and everything about Bumblebee.

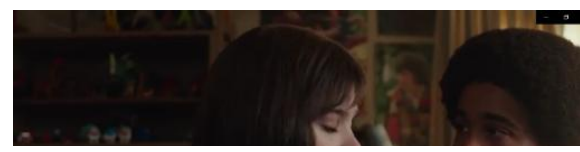

Figure 14. When Charlie curious about the car $(0: 31: 13)$

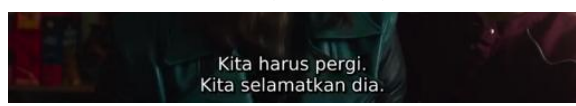

Curiosity in this movie could be describe in scene and dialog as follow:

Charlie : "Hi," (approach)

Bumblebee : (saying something)

Charlie : "Oh my god. Do you speak?"

Charlie : "I won't hurt you. Can you understand me?"

Charlie approach to Bumblebee and touch his face

Charlie : "What are you? Where did you come from?"

Charlie saw the car was changed into a robot, she was shocked and want to run. But when she saw the robot, she closed the door because she taught that he was kind. Then, Charlie approached him and heard he said something then she asked about is he can speak or not. And after that, she asked everything to Bumblebee.

Curiosity is when attitudes and actions that always strive to find out more deeply and extensively from something that is learned, seen, and heard. Samani and Hariyanto stated that curiosity (curiosity) is the desire to investigate and seek understanding of natural secrets or social events that are happening. For example, curious about something that has never been found, curious about someone and many more.

In the dialog "What are you? Where did you come from?" shows curiosity, shows interest so Charlie is curious about things about Bumblebee. Asking who is he and where did he come from is a sign that Charlie curious about Bumblebee. She wants to know more deeply about Bumblebee.

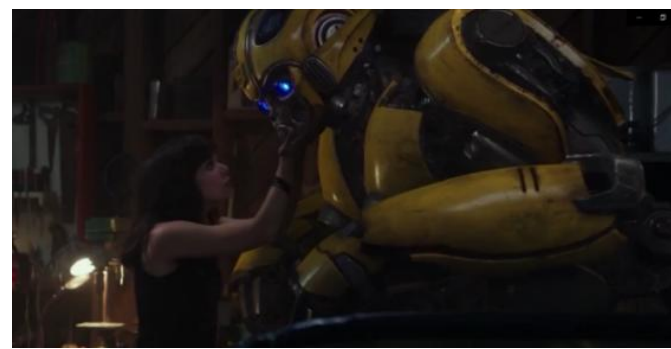

Figure 15. When Charlie ask to Bumblebee (0:42:12)

Curiosity in this movie could be describe in scene and dialog as follow:

Charlie

Charlie

Charlie
: "It sucked being couped up in a VW all day, huh?"

: "Is there-- anyone can help you?"

: "Do you have a family? You know, like a mom, dad, or siblings. You all love each other or drive each other crazy and you can't wait to get away and start your own life."

After teaching Bumblebee some things that should and should not be done, they walk around the forest. At that moment Charlie asked Bumblebee a lot of questions. Charlie didn't stop asking questions about deep things. Then Bumblebee shows Charlie his broken part and asks him to fix it.

From the dialog above, the writer can say that Charlie was so curious about Bumblebee. She asked many things like "It sucked being couped up in a VW all day, huh?" and she also asked to him "Is there-anyone can help you?" and about his family or parents and much more because Charlie is so curious about it. She wants to know every single thing from Bumblebee. But Bumblebee can't answer it because his radio was broken and he can't speak anymore. So, he asked to Charlie to fix his radio.

There are 4 kinds of moral values that most appear in this movie, they are Work hard, creative, care to social, and curious. The reason is that Bumblebee movie is the movie that shows care. Work hard because Charlie Watson is a hard worker that has high creativity in fixing machine. Curious because Bumblebee and Charlie have high curiosity, they want to know each other about themselves. It's a story between robots and humans.

\section{CONCLUSION}

After watching and analyzing Bumblebee movie, the writer can conclude two main points have been discussed in this paper. There are types of moral values from the main character and moral values most appear in Bumblebee movie. In this movie, the main characters are Charlie Watson and Bumblebee.

First, it is about analyzing moral value in the main character, Charlie Watson. There are eight types of moral values from Charlie Watson's character. They are work hard, care to social, creative, curious, friendly or communicative, independent, and appreciate achievement.

Second, it is about types of moral values that most appear in Bumblebee movie. There are 4 moral value most appear in the movie, they are work hard, creative, care to social, and curiosity.

\section{BIBLIOGRAPHY}

Am, Y. T., Kuncara, S. D., \& Setyowati, R. (2017). Analysis of the Main Character Needs in Life 
of Pi Movie Using Maslow' S Theory.

Effendi. (2015). Understanding Human Development.

Fani, S. A. (2018). The Schizophrenia in The Main Character of A Beautiful Mind movie Directed by Ron Howard. Wanastra: Jurnal Bahasa Dan Sastra, 10(1), 9-16. http://ejournal.bsi.ac.id/ejurnal/index.php/wana stra/article/view/2648/2061\%0A\%0A

Lindy, T. R. (2018). AN ANALYSIS OF MAIN CHARACTER ' S MOTIVATION IN THE BOOK THIEF FILM ENGLISH EDUCATION STUDY PROGRAM LANGUAGE AND ARTS FACULTY OF TEACHER TRAINING AND EDUCATION.

M, S. (2010). What's in a name? Qualitative description revisited. Research in Nursing \& Health, 33(1), 77-84.

Mulyasa, E. (2009). Menjadi Guru Profesional Menciptakan Pembelajaran Kreatif dan Menyenangkan.

Nuriadi. (2016). Theory of Literature: An Introduction.

Sugiyono. (2011). Metode Penelitian Kuantitatif Kualitatif dan $R \& D$.

Wellek, Rene; Warren, A. (1948). Theory of Literature. 